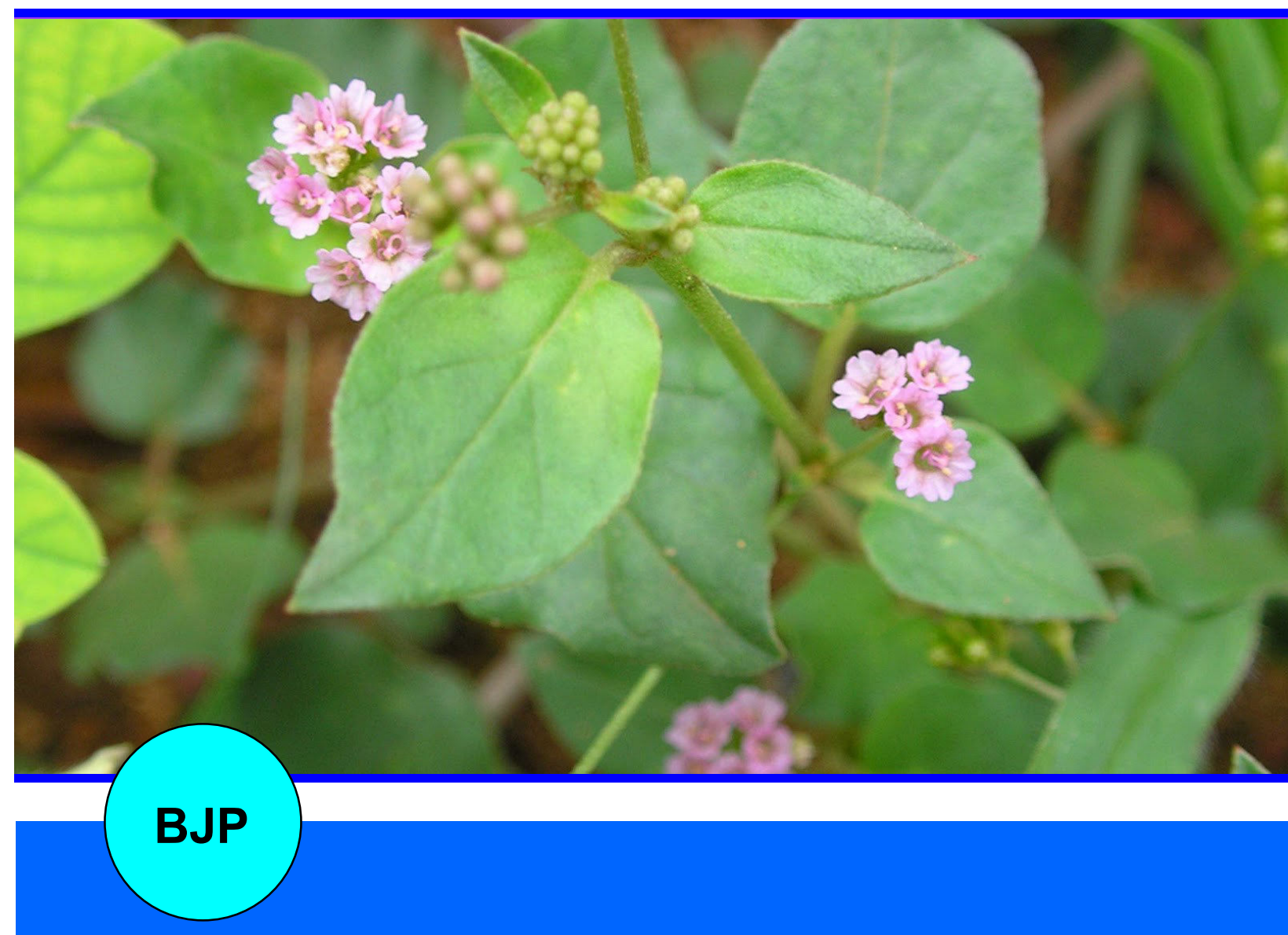

Bangladesh Journal of Pharmacology

Research Article

Chemical composition, phytochemical analysis and antimicrobial activity of Boerhavia procumbens 
Abstracted/indexed in Academic Search Complete, Asia Journals Online, Bangladesh Journals Online, Biological Abstracts, BIOSIS Previews, CAB Abstracts, Current Abstracts, Directory of Open Access Journals, EMBASE/Excerpta Medica, Global Health, Google Scholar, HINARI (WHO), International Pharmaceutical Abstracts, Open J-gate, Science Citation Index Expanded, SCOPUS and Social Sciences Citation Index;

ISSN: $1991-0088$

\title{
Chemical composition, phytochemical analysis and antimicrobial activity of Boerhavia procumbens
}

\author{
Abdul Wajid Khalil'1,2, Zafar Iqbal' ${ }^{1}$ and Achyut Adhikari3 \\ ${ }^{1}$ Department of Agricultural Chemistry, University of Agriculture, Peshawar 25120, Pakistan; ${ }^{2}$ Pakistan Council of \\ Scientific and Industrial Research (PCSIR) Laboratories Complex, Peshawar 25120, Pakistan; ${ }^{3}$ HEJ Research \\ Institute, ICCBS, Karachi University, Karachi 75270, Pakistan.
}

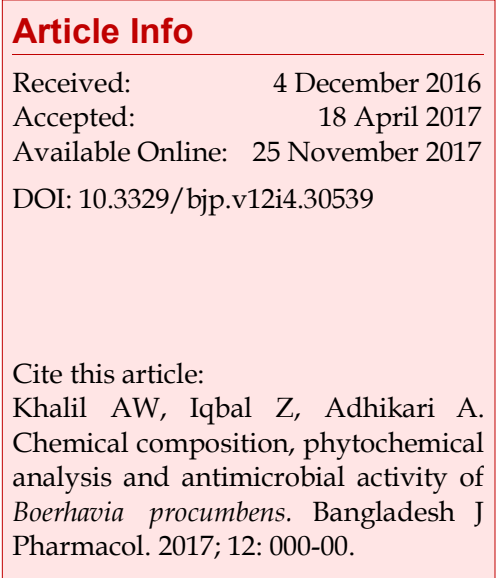

\begin{abstract}
Boerhavia procumbens is a medicinal herb used in the treatment of various ailments including asthma, cough and jaundice. The concentration of calcium (280.7 $\pm 0.0 \mathrm{mg} / 100 \mathrm{~g}, 102.3 \pm 0.0 \mathrm{mg} / 100 \mathrm{~g})$, potassium $(240.4 \pm 0.0 \mathrm{mg} / 100 \mathrm{~g}$, $92.1 \pm 0.0 \mathrm{mg} / 100 \mathrm{~g})$, aspartic acid $(30.9 \pm 0.0 \mathrm{~g} / 100 \mathrm{~g}, 26.1 \pm 0.0 \mathrm{~g} / 100 \mathrm{~g})$, glutamicacid $(25.2 \pm 0.0 \mathrm{~g} / 100 \mathrm{~g}, 17.7 \pm 0.0 \mathrm{~g} / 100 \mathrm{~g})$ and alanine were the abundant in the stem and root than leaf while carbohydrate $(79.9 \pm 0.0 \%)$ was found higher in the leaf of B. procumbens. The leaf and root extracts revealed the presence of alkaloids, flavonoids, tannins and phenol. Leaf extract was found to be more active against $S$. aureus $(11.5 \pm 0.3 \mathrm{~mm}), C$. michiganensis $(12.1 \pm 0.2 \mathrm{~mm})$ and $F$. oxysporum $(23.6 \pm 0.2 \mathrm{~mm})$ than the root extract of $B$. procumbens. It is concluded that stem and root of $B$. procumbens contain essential nutrients and the antimicrobial study encourages the use of leaf extract for the treatment of most common microbial diseases.
\end{abstract}

\section{Introduction}

Boerhavia procumbens (Family Nyctaginaceae) is an herbaceous, widespread tropical herb, occurs plentifully as a weed and found in the plains, waste places in clay loam soil. It has been traditionally used for the treatment of jaundice, enlarged spleen, dyspepsia, abdominal pain and stress condition (Sankaranarayanan et al., 2010). Some of the other biological activities of $B$. procumbens include anti-asthmatic (Bokhari and Khan, 2015), anti-inflammatory and anti-oxidant (Bokhari et al., 2015). It has reported a multitude of phytochemical constituents such as alkaloids, phenolics, flavonoids and cardiac glycosides in the plant sample. Several studies indicate that every part of the plant sample contained vital nutrients such as carbohydrates, protein, lipids, minerals and amino acid profile in the genus of Boerhavia (Ujowundu et al., 2008; Miralles et al., 1988).
The therapeutic efficacy of herbal plants is on the basis of proximate and elemental compositions. It has been reported that $B$. procumbens can be used as food along with its medicinal benefits and assessing the nutritional values which can help to understand the value of this plant (Shinwari et al., 2015).

The analyses of proximate and elemental composition in herbal plants are not sufficient to know their therapeutic potential as it may also depend on the amino acid compositions (Ahmad et al., 1994). Amino acids are essential in the synthesis of protein and act as precursors in the formation of secondary metabolite compounds (Pérez-Urria and Avalos García, 2009). These compounds are known to be biologically active and therefore, aid in the antimicrobial activity of plant used in this study.

The antibiotic play crucial role in the extenuation of various ailments but it produce side effects such as the 
appearance of multidrug resistant pathogenic species and the outbreak of the new contagious diseases (Abdalla, 2011; Shaheen et al., 2012; Shinwari et al., 2012). In the prevailing situation, the appearance of varied drug resistance to human pathogenic organisms, there is a need to search for new antimicrobial agents from various plant sources (Gul et al., 2012; Nadeem et al., 2013; Rajkumar and Malathi, 2015; Calni et al., 2016).

Keeping in view the importance of B. procumbens as a natural and traditional healer, it was felt necessary to analyze proximate, elemental, amino acid compositions along with phytochemical and antimicrobial analysis of its leaf, stem and root, which may provide a scientific database for the researchers.

\section{Materials and Methods}

\section{Collection of plant materials}

The plant sample was collected during flowering season in the month of June from the botanical garden of PCSIR Labs. Complex Peshawar, Pakistan and identified by the taxonomist at the Department of Botany, University of Peshawar, Pakistan. A voucher specimen (Catalogue No. Bot. 20077) has been deposited in the herbarium of University of Peshawar for future reference.

\section{Processing of the plant}

The whole plant was washed with tap water and dried under shade at room temperature for a period of 7-10 days. The leaf, stem and root of the dried plant were separated and pulverized in a Willy mill. The pulverized part of the plant (150 g of each part) was divided into two portions. One portion was used for the analysis of chemical composition. The second portion was macerated in $80 \%$ methanol in a glass jar for 72 hours with occasional shaking throughout the period. The separated extract was then filtered through Whatman No. 1 filter paper. The methanol filtrate was evaporated to dryness using rotary vacuum evaporator (Buchi, Switzerland) under reduced pressure and temperature at $40-45^{\circ} \mathrm{C}$ to obtain a greenish brown residue. The dried extracts were kept in an air tight glass jar and stored at $4^{\circ} \mathrm{C}$ in a refrigerator until used for phytochemical screening and antimicrobial activity.

\section{Proximate composition}

Proximate analysis of the leaf, stem and root of $B$. procumbens were carried out in triplicate for measuring moisture, inorganic matter, lipids, protein and fiber contents by methods as described previously (AOAC, 2005). Ash content (inorganic matter) was analyzed by dry ashing method. The moisture contents were conducted through an oven at a temperature of $105^{\circ} \mathrm{C}$. The crude fat was extracted through Soxhlet apparatus in an organic solvent (petroleum ether) at $40-60^{\circ} \mathrm{C}$ and the crude fiber was investigated by titrimetric method. Auto-Kjeldahl equipment was used for the assessment of nitrogen while the total protein content was calculated as $N \times$ Factor (100/16: 6.25). The amount of nitrogen free extract (carbohydrate) was calculated by the difference between the weight of the sample taken and the sum of its moisture content, inorganic matter, crude lipid, crude protein, and fiber as described previously (James, 1995).

Percent digestible carbohydrate was calculated as

$=100-(\%$ Moisture $+\%$ Crude fiber $+\%$ Inorganic matter $+\%$ Crude lipid $+\%$ Crude protein)

\section{Minerals composition}

\section{Dry ashing}

This process was carried out according to the method (AOAC, 2000) with slight modifications in the procedure of the preparation of ash solution (Hussain et al., 2005). The powdered sample of the leaf, stem and root were placed in a crucible for charring process. The process was accomplished on a low flame inside a fume hood till all the organic matter was decomposed completely. The carbon-free sample was then ashed in a muffle furnace (MTI Corporation, USA) at $600^{\circ} \mathrm{C}$ for 5 hours. The grey-white ash was dissolved in $2 \mathrm{~mL}$ concentrated $\mathrm{HNO}_{3}$ (Merck) and heated on a low flame for $1 \mathrm{~min}$. Afterward, it was cooled and filtered through Whatman No. 42 filter paper and the volume was made up with triple distilled water (Germany) in a $50 \mathrm{~mL}$ volumetric flask. A blank sample was also prepared using a similar experimental procedure. The minerals analysis was performed in replicates in the study.

\section{Instrumentation}

The concentrations of mineral elements like $\mathrm{Fe}, \mathrm{Cu}, \mathrm{Zn}$, $\mathrm{Cr}, \mathrm{Cd}, \mathrm{Pb}, \mathrm{Ar}, \mathrm{Mn}$ and $\mathrm{Ni}$ were determined through flame atomic absorption spectrometer (Hitachi Polarized Z-8000 Japan) and the macro-elements like $\mathrm{Na}, \mathrm{K}$ and $\mathrm{Ca}$ were analyzed using flame photometer (Jenway PFP7, UK).

\section{Amino acid composition}

\section{Sample preparation}

Normal hydrolysis was carried out by the method described in HPLC amino acid analysis system application data book (Shimadzu). Sample (23.3 mg) was taken in separate digestion tube with the addition of $\mathrm{HCl}(6$ $\mathrm{N} ; 2 \mathrm{~mL}$ ) and kept for $18-24$ hours at $110^{\circ} \mathrm{C}$ under vacuum. The hydrolyzed sample was then washed with water and evaporated to dryness on a rotary evaporator in vacuo, at $70^{\circ} \mathrm{C}$. The final volume was made up at 10 $\mathrm{mL}$ with deionized water. The sample was then filtered through a syringe filter ( 0.22 micron) and diluted with buffer A solution in a sample vial, prior to injection (20 
$\mu \mathrm{L})$ into the amino acid analyzer.

\section{Instrumental conditions}

Amino acid analysis was conducted on the Shimadzu Amino Acid Analyzer with Shim-Pack Amino- Na column $(4.6 \mathrm{~mm}$, I.D $\times 100 \mathrm{~mm})$. Sample was injected by the auto injector. The mobile phase consisted of $0.2 \mathrm{~N}$ sodium citrate ( $\mathrm{pH} 3.2, \mathrm{MA}), 0.6 \mathrm{~N}$ sodium citrate and $0.2 \mathrm{M}$ boric acid ( $\mathrm{pH} 10, \mathrm{MB})$, and $0.2 \mathrm{M} \mathrm{NaOH}$ (MC). A gradient program of $72 \mathrm{~min}$ was set for mobile phase $\mathrm{A}$, $\mathrm{B}, \mathrm{C}$ with the initial flow rate of $0.4 \mathrm{~mL} / \mathrm{min}$. Ammonia trap column was used prior to column elution. Reaction solutions were kept at a flow rate of $2 \mathrm{~mL} / \mathrm{min}$ at $60^{\circ} \mathrm{C}$. The column oven was set at $60^{\circ} \mathrm{C}$. Flow rate of reaction solution was kept constant by peristaltic pump.

\section{Phytochemical analysis}

The preliminary screening of phytochemical constituents of methanol extract of the leaf, stem and root of the study plant were done for the investigation of secondary metabolites compounds such as alkaloids, flavonoids, saponins, tannins, phenols, and steroidal glycolsides by using the standard procedures (Sofowora, 1993; Trease and Evans, 2002; Harborne, 1973; Parekh and Chanda, 2008).

\section{Antimicrobial assay}

\section{Strains and culture media}

The antimicrobial activity of methanol extracted samples from the leaf, stem and root was tested against Gram positive bacteria: Staphylococcus aureus: ATCC No. 6538, Bacillus subtilis, Clavibacter michiganensis and Gram negative bacteria: Escherichia coli: ATCC No. 15224, Klebsiella pneumonia, Pseudomonas aeruginosa: ATCC No. 9721, Xanthomonas campestris and Proteus vulgaris followed by antifungal activity against Fusarium oxysporum, Fusarium solani: FCBP No. 0291, Aspergillus niger: FCBP No. 0198, Musculus piriformis and Aspergillus flavus: FCBP No. 0064. All the tested microorganisms were procured from the Department of Microbiology, Quaid-e-Azam University Islamabad, Pakistan. The purity and identity of the strains were verified by the Department of Plant Pathology, University of Agriculture Peshawar, Pakistan. Bacterial strains were cultured and maintained on nutrient agar slants and incubated at $37^{\circ} \mathrm{C}$ while fungal strains were cultured and maintained on potato dextrose agar at $28-30^{\circ} \mathrm{C}$. Stock cultures of bacteria and fungi were maintained at $4^{\circ} \mathrm{C}$.

\section{Disc diffusion method}

The antibacterial and antifungal activities were evaluated by disc diffusion following the method described by the National Committee for Clinical Laboratory Standard (NCCLS, 2002). The discs of Whatman No. 1 filter paper, $6 \mathrm{~mm}$ in diameter, were used to screen out the antimicrobial activity. A sterile disc was impregnated with $100 \mathrm{mg}$ of samples extract/mL ( $20 \mu \mathrm{L} /$ disc) placed on the inoculated agar. Cefixime (standard antibacterial) was served as a positive control for bacteria and clotrimazole $(30 \mu \mathrm{g} / \mathrm{mL})$ as a positive control for fungi while DMSO was used as a negative control. Bacteria were incubated at $37^{\circ} \mathrm{C}$ for $18-24$ hours whereas, the fungi at $30^{\circ} \mathrm{C}$ for $24-72$ hours. At the end of the incubation period, the antimicrobial activity was evaluated by measuring the diameter of the zone of inhibition ( $\mathrm{mm}$ ) of the samples as well as control treated discs. The analysis was performed in triplicate.

\section{Statistical analysis}

In this study, all the results were expressed as mean values of three replicates \pm standard deviation. The significance difference was determined using Statistix 8.1 computer software by performing one-way (ANOVA). The comparisons among means were carried out using Least Significant Difference (LSD) test at $5 \%$ level of significance (Steel et al., 1997).

\section{Results}

In the proximate analysis, the moisture content (Table I) was determined on the wet basis while other parameters on the dry weight basis in leaf, stem and root of $B$. procumbens. The moisture content of the root $(7.4 \pm 0.0 \%)$ was higher as compared to stem (5.7 \pm $0.0 \%)$ and leaf $(6.2 \pm 0.0 \%)$. The protein and inorganic matter of the root $(37.5 \pm 0.0 \%, 21.3 \pm 0.0 \%)$ were significantly higher at $(\mathrm{p}<0.05)$ than those of the leaf $(0.7 \pm 0.0,11.1 \pm 0.0)$ and stem $(6.3 \pm 0.0 \%, 2.0 \pm 0.0 \%)$ of plant sample. The value of crude fiber $(6.6 \pm 0.0 \%)$ was found higher in the stem as compared to leaf and root. The higher values of carbohydrate was recorded in the leaf $(79.2 \pm 0.0 \%)$ followed by the stem $(78.7 \pm 0.0 \%)$ than the root.

Results show that calcium and potassium were the highest elements in the stem and root of the study plant species. Sodium $(30.3 \pm 0.0 \mathrm{mg} / 100 \mathrm{~g})$ and iron (32.6 \pm $0.0 \mathrm{mg} / 100 \mathrm{~g}$ ) were found to be significantly higher in concentration $(\mathrm{p}<0.05)$ in stem as compared to the leaf while iron content $(80.3 \pm 0.0)$ was recorded higher in the root than the leaf and stem. A similar trend was also observed in the root for $\mathrm{Cu}$ and $\mathrm{Zn}(6.9 \pm 0.0 \mathrm{mg} / 100 \mathrm{~g}$, $2.7 \pm 0.0 \mathrm{mg} / 100 \mathrm{~g})$ than the stem and leaf. Nickel content was recorded lowest in the leaf, root and stem whereas $\mathrm{Cd}$ was not detectable in the same parts of plant.

The highest concentration of non-essential amino acids in the stem and root was aspartic acid $(30.9 \pm 0.1 \mathrm{~g} / 100$ $\mathrm{g}, 26.1 \pm 0.0 \mathrm{~g} / 100 \mathrm{~g})$, glutamic acid $(25.2 \pm 0.0 \mathrm{~g} / 100 \mathrm{~g}$, $17.7 \pm 0.0 \mathrm{~g} / 100 \mathrm{~g})$ and alanine $(12.9 \pm 0.0 \mathrm{~g} / 100 \mathrm{~g}, 7.9 \pm$ $0.0 \mathrm{~g} / 100 \mathrm{~g})$. On the other hand, the higher amount of 
Table I

Proximate (\%), minerals (mg/100 g) and amino acids compositions $(\mathrm{g} / 100 \mathrm{~g})$ of $B$. procumbens

\begin{tabular}{|c|c|c|c|}
\hline \multirow[t]{2}{*}{ Compositions } & \multicolumn{3}{|c|}{ Boerhavia procumbens } \\
\hline & Leaf & Stem & Root \\
\hline \multicolumn{4}{|l|}{ Proximate } \\
\hline Moisture & $6.2 \pm 0.0^{b}$ & $5.7 \pm 0.0 c$ & $7.4 \pm 0.0^{a}$ \\
\hline Inorganic matter & $11.1 \pm 0.0^{\mathrm{b}}$ & $2.0 \pm 0.0 c$ & $21.3 \pm 0.0^{a}$ \\
\hline Crude protein & $0.7 \pm 0.0 c$ & $6.3 \pm 0.0^{\mathrm{b}}$ & $37.5 \pm 0.0^{a}$ \\
\hline Crude fiber & $2.1 \pm 0.0^{b}$ & $6.6 \pm 0.0^{a}$ & $1.0 \pm 0.0^{\circ}$ \\
\hline Crude fat & $0.6 \pm 0.0^{b}$ & $0.6 \pm 0.0 c$ & $1.8 \pm 0.0^{a}$ \\
\hline Carbohydrate & $79.2 \pm 0.03^{a}$ & $78.7 \pm 0.0^{b}$ & $31.3 \pm 0.0$ \\
\hline \multicolumn{4}{|l|}{ Minerals } \\
\hline $\mathrm{Na}$ & $18.4 \pm 0.0^{b}$ & $30.3 \pm 0.0^{a}$ & $2.2 \pm 0.0^{\circ}$ \\
\hline $\mathrm{Ca}$ & $60.2 \pm 0.1^{c}$ & $280.7 \pm 0.0^{\mathrm{a}}$ & $102.3 \pm 0.0^{\mathrm{b}}$ \\
\hline K & $5.3 \pm 0.0^{c}$ & $240.4 \pm 0.0^{a}$ & $92.1 \pm 0.0^{b}$ \\
\hline $\mathrm{Fe}$ & $30.5 \pm 0.0 c$ & $32.6 \pm 0.0^{b}$ & $80.3 \pm 0.0^{a}$ \\
\hline $\mathrm{Zn}$ & $1.3 \pm 0.0 c$ & $1.7 \pm 0.0^{\mathrm{b}}$ & $2.7 \pm 0.0$ a \\
\hline $\mathrm{Cu}$ & $1.6 \pm 0.1^{b}$ & $0.6 \pm 0.0^{c}$ & $6.9 \pm 0.0 \mathrm{a}$ \\
\hline $\mathrm{Ni}$ & $0.1 \pm 0.0^{b}$ & $0.1 \pm 0.0^{a}$ & $0.1 \pm 0.0^{\mathrm{ab}}$ \\
\hline $\mathrm{Cr}$ & $0.2 \pm 0.0^{b}$ & $0.1 \pm 0.0^{c}$ & $0.3 \pm 0.0^{a}$ \\
\hline $\mathrm{Pb}$ & $1.9 \pm 0.0^{b}$ & $2.8 \pm 0.0^{a}$ & $0.9 \pm 0.1$ \\
\hline $\mathrm{Cd}$ & ND & ND & ND \\
\hline $\mathrm{Ar}$ & $0.2 \pm 0.0 c$ & $0.3 \pm 0.1^{a}$ & $0.7 \pm 0.1^{b}$ \\
\hline \multicolumn{4}{|l|}{ Amino acids } \\
\hline Aspartic acid & $0.0 \pm 0.0 c$ & $30.9 \pm 0.1^{a}$ & $26.1 \pm 0.0^{b}$ \\
\hline Glutamic acid & $0.1 \pm 0.0 c$ & $25.2 \pm 0.0^{a}$ & $17.7 \pm 0.0^{b}$ \\
\hline Alanine & $0.1 \pm 0.0^{c}$ & $12.9 \pm 0.0^{a}$ & $7.9 \pm 0.0^{b}$ \\
\hline Glycine & $0.0 \pm 0.0^{c}$ & $7.8 \pm 0.0^{\mathrm{a}}$ & $5.7 \pm 0.1^{b}$ \\
\hline Proline & ND & ND & $0.7 \pm 0.0$ a \\
\hline Tyrosine & ND & $0.8 \pm 0.5^{a}$ & $0.5 \pm 0.0^{\mathrm{b}}$ \\
\hline Cysteine & $0.1 \pm 0.0^{c}$ & $0.2 \pm 0.0^{\mathrm{b}}$ & $1.8 \pm 0.0$ a \\
\hline Threonine & $0.0 \pm 0.0 c$ & $0.4 \pm 0.0^{\mathrm{b}}$ & $3.6 \pm 0.0$ \\
\hline Tryptophan & $0.2 \pm 0.0^{c}$ & $6.2 \pm 0.0^{\mathrm{b}}$ & $8.9 \pm 0.0$ \\
\hline Histidine & $0.0 \pm 0.0$ & $0.8 \pm 0.0^{a}$ & $0.7 \pm 0.0$ a \\
\hline Arginine & $0.1 \pm 0.0^{c}$ & $3.7 \pm 0.0^{\mathrm{b}}$ & $8.9 \pm 0.0$ \\
\hline Lysine & $0.0 \pm 0.0$ & $0.4 \pm 0.0^{\mathrm{b}}$ & $4.8 \pm 0.0^{a}$ \\
\hline Leucine & $0.0 \pm 0.0$ & $0.7 \pm 0.1^{a}$ & $0.7 \pm 0.0$ a \\
\hline Methionine & $0.1 \pm 0.0 c$ & $1.1 \pm 0.0^{\mathrm{b}}$ & $3.8 \pm 0.0$ a \\
\hline Valine & $0.1 \pm 0.0 c$ & $3.6 \pm 0.0^{a}$ & $2.9 \pm 0.0^{b}$ \\
\hline Phenylalanine & $0.1 \pm 0.0 c$ & $1.8 \pm 0.0^{\mathrm{b}}$ & $3.4 \pm 0.0^{a}$ \\
\hline
\end{tabular}

Values are mean $\pm S D ; n=3$. Means followed by different superscript in the same row are significantly different at $(\mathrm{p}<0.05)$. ND: Not detected

essential amino acid of tryptophan was recorded in the $\operatorname{root}(8.9 \pm 0.0 \mathrm{~g} / 100 \mathrm{~g})$ and stem $(6.2 \pm 0.0 \mathrm{~g} / 100 \mathrm{~g})$ as compared to the leaf. A similar trend was also found in roots and stem for arginine. In the study, histidine and leucine were not found significantly different $(p>0.05)$.
Table II

Phytochemical screening of the methanol extract of leaf, stem and root of $B$. procumbens

\begin{tabular}{lccc|} 
Phytochemical con- & \multicolumn{3}{c|}{ Boerhavia procumbens } \\
\cline { 2 - 4 } stituents & $\begin{array}{c}\text { Leaf } \\
\text { extract }\end{array}$ & $\begin{array}{c}\text { Stem } \\
\text { extract }\end{array}$ & $\begin{array}{c}\text { Root } \\
\text { extract }\end{array}$ \\
Alkaloids & +++ & +++ & ++ \\
Flavonoids & - & + & + \\
Tannins & ++++ & ++ & - \\
Saponins & ++ & ++ & ++ \\
Phenols & +++ & ++ & ++ \\
Steroidal glycosides & + & + & - \\
\hline
\end{tabular}

- Absent; + Less; + + Moderate; + + + High; + + + + very high

Tannins were found in leaf extract as compared to stem and root extracts (Table II). The contents of alkaloids and phenol were also found in the leaf extract than the stem and root extracts. Saponins compounds were present in the extracts of all parts of the plant. The flavonoids compound was absent in the leaf while found in the stem and root extracts.

Leaf extract was found effective against K. pneumonia, E. coli and S. aureus having zone of inhibition of $19.6 \pm 0.3$, $11.3 \pm 0.2$ and $11.5 \pm 0.3 \mathrm{~mm}$ respectively than stem and root extracts (Table III). Stem and leaf extracts revealed no inhibitory activity against $P$. vulgaris as compared to root extract with least activity. In case of plant pathogenic bacteria, the stem extract exhibited significant activity against $X$. campestris $(12.6 \pm 0.3 \mathrm{~mm})$. The stem and leaf extracts also showed higher level of zone inhibition of $10.7 \pm 0.1$ and $12.1 \pm 0.3 \mathrm{~mm}$ against C. michiganensis as compared to the root extract.

The antifungal activity of leaf, stem and root extracts showed varied growth of fungal inhibition (Table III). Leaf extract showed to be the most effective in inhibiting the growth of F. oxysporum $(23.6 \pm 0.2 \mathrm{~mm})$ than stem and root extracts. F. solani displayed similar growth against stem and roots extracts and was not found significantly different at value $(\mathrm{p}>0.05)$. A. niger and $A$. flavus exhibited an early similar diameter of the growth of colonies up to $14.4 \pm 0.1$ and $14.6 \pm 0.2 \mathrm{~mm}$ in the leaf extract respectively. Root extract showed some activity against $M$. piriformis.

\section{Discussion}

Higher level of carbohydrate was detected in the leaf of plant sample, while the high contents of protein in the root can be used as vegetables to supplement the predominant starchy staple foods. Similarly, high amount of inorganic matter found in the root indicates that it is rich in minerals. In addition, the comparatively highfiber level and low-fat contents in the stem may be an 
Table III

Zone of inhibitory activity $(\mathrm{mm})$ of stem, leaf and root extracts of $B$. procumbens against bacterial and fungal strains

\begin{tabular}{lcccc|}
\hline & \multicolumn{3}{c}{ Boerhavia procumbens } \\
\cline { 2 - 4 } Strains & Stem extract & Leaf extract & Root extract & $\begin{array}{c}\text { Standards } \\
\text { Cefaxime }\end{array}$ \\
X. campestris & & & & $13.3 \pm 0.1 \mathrm{a}$ \\
P. vulgaris & $12.6 \pm 0.3 \mathrm{~b}$ & $0.0 \pm 0.0 \mathrm{~d}$ & $8.5 \pm 0.2 \mathrm{c}$ & $11.3 \pm 0.2 \mathrm{a}$ \\
E.coli & $0.0 \pm 0.0 \mathrm{c}$ & $0.0 \pm 0.0 \mathrm{c}$ & $6.5 \pm 0.3 \mathrm{~b}$ & $12.3 \pm 0.1 \mathrm{a}$ \\
S. aureus & $9.6 \pm 0.3 \mathrm{c}$ & $11.3 \pm 0.2 \mathrm{~b}$ & $8.5 \pm 0.2 \mathrm{~d}$ & $11.5 \pm 0.2 \mathrm{a}$ \\
K. pneumonia & $8.5 \pm 0.1 \mathrm{c}$ & $11.5 \pm 0.3 \mathrm{~b}$ & $7.5 \pm 0.2 \mathrm{~d}$ & $20.5 \pm 0.2 \mathrm{a}$ \\
P. aerugonosa & $12.6 \pm 0.2 \mathrm{~d}$ & $19.6 \pm 0.3 \mathrm{~b}$ & $15.6 \pm 0.2 \mathrm{c}$ & $18.6 \pm 0.2 \mathrm{a}$ \\
B. subtilis & $12.4 \pm 0.2 \mathrm{c}$ & $8.9 \pm 0.3 \mathrm{~b}$ & $16.5 \pm 0.2 \mathrm{~d}$ & $19.3 \pm 0.2 \mathrm{a}$ \\
C. michiganensis & $12.5 \pm 0.2 \mathrm{~d}$ & $10.5 \pm 0.2 \mathrm{~b}$ & $13.6 \pm 0.2 \mathrm{c}$ & $12.4 \pm 0.2 \mathrm{a}$ \\
Fungal strains & $10.7 \pm 0.1 \mathrm{c}$ & $12.1 \pm 0.3 \mathrm{~b}$ & $8.7 \pm 0.2 \mathrm{~d}$ & Clotrimazole \\
F. oxysporum & & & & $23.2 \pm 0.2 \mathrm{a}$ \\
F. solani & $15.7 \pm 0.2 \mathrm{c}$ & $23.6 \pm 0.2 \mathrm{a}$ & $18.6 \pm 0.2 \mathrm{~b}$ & $15.6 \pm 0.3 \mathrm{a}$ \\
A. niger & $8.6 \pm 0.2 \mathrm{c}$ & $13.3 \pm 0.2 \mathrm{~b}$ & $8.5 \pm 0.2 \mathrm{c}$ & $17.4 \pm 0.2 \mathrm{a}$ \\
M. piriformis & $0.0 \pm 0.0 \mathrm{~d}$ & $14.4 \pm 0.1 \mathrm{~b}$ & $10.6 \pm 0.2 \mathrm{c}$ & $24.4 \pm 0.2 \mathrm{a}$ \\
A. flavus & $8.5 \pm 0.3 \mathrm{c}$ & $0.0 \pm 0.0 \mathrm{~d}$ & $12.5 \pm 0.3 \mathrm{~b}$ & $15.5 \pm 0.2 \mathrm{a}$ \\
\hline
\end{tabular}

Values are mean $\pm S D ; n=3$. Means followed by different superscripts in the same rows are significantly different using LSD value at $p<0.05$

important contributing factor in the applications of medicinal plant. Juna Beegum et al. (2014) reported the higher concentration of carbohydrate and protein in leaf and root than the whole plant of $B$. diffusa respectively. The moisture contents, crude protein and fat in leaf of plant sample were found lower as observed in the leaf of $B$. diffusa have been reported previously (Gupta and Yadav, 2013).

In this study, the highest element among the macrominerals in stem and root was calcium and potassium. It has been reported that calcium is the simplest and cheapest approach for reducing risks of osteoporosis (Wallace et al., 2004). The highest calcium level in stem suggests that the plant can be used as a supplement in the diet for the treatment and prevention of osteoporosis. Similarly, the presence of a suitable amount of iron indicates that the stem can also be used to improve the anemic condition of a patient. The value of $\mathrm{Na} / \mathrm{K}$ ratio of stem and root were 0.1 and 0.02 which is less than 0.6 of the recommended value for hypertensive patients (Nieman et al., 1992). So, $\mathrm{Na} / \mathrm{K}$ ratio in the stem and root is of great concern in the body for prevention of high blood pressure. Therefore, these parts (stem and root) may have a beneficial effect on hypertensive patients. In toxic metals, cadmium is not detected, whereas the concentration of arsenic and lead are lower than the permissible limits (WHO, 1998).

The data of the toxic metals show that every part of this plant is safe for human consumption that can be used in the preparation of herbal medicine. Abd EI-Salam et al. (2013) reported the value of iron and zinc in the root $(117.9,46 \mathrm{mg} / \mathrm{kg})$, stem $(82,23.6 \mathrm{mg} / \mathrm{kg})$ and leaf (97, $21.8 \mathrm{mg} / \mathrm{kg}$ ) of B. procumbens was found higher than the results of our study. In the present study, the leaf of sample has lower concentrations of sodium (18.4 \pm 0.1 $\mathrm{mg} / 100 \mathrm{~g})$ and calcium $(60.2 \pm 0.1 \mathrm{mg} / 100 \mathrm{~g})$ while potassium and iron have higher contents in comparison with those reported earlier (Puranik et al., 2012).

Glutamic and aspartic acids are used in higher concentration for the stimulation of brain activities and maintain the cognitive functions of the brain (Leon, 1986; McEntee and Crook, 1993). In this study, the aspartic acid and glutamic acid are recorded in higher amount in the roots and stem. It is suggested that these parts of the plant sample can be used as neurotransmitters and stabilizing agent for the brain. Other interesting amino acids such as tryptophan and arginine found in the same parts of $B$. procumbens are involved in modulating neurological and immunological functions through multiple metabolites, including serotonin and melatonin.

The phytochemical screening of the leaf, stem and roots extracts of the study plant species confirms the presence of tannin, alkaloids, phenol and saponins in leaf and root extracts. These secondary metabolite compounds are known to be biologically active and possess significant pharmacological activity such as anti-inflammatory, analgesic, antibacterial and antibiotic. In this 
study, tannin was the most abundant compound in leaf extract and exerts antimicrobial activity through different mechanisms as tannins form irreversible complexes with proline-rich protein (Shimada, 2006) resulting in the inhibition of cell protein synthesis of the microbes.

Our results indicate that the leaf extract is more effective in inhibiting the growth of pathogenic bacterial and fungal strains. This activity of leaf extract is due to its phytochemical constituents such as alkaloids, flavonoids, tannins, phenols, saponins, and several other aromatic compounds (Bonjar et al., 2004). These bioactive compounds inhibit the growth of many human diseases and infections causing by micro-organisms (Cowan, 1999). Moreover, these bioactive compounds delay the growth of microbes by attaching to their surface proteins, breaking the peptide bonds, changing their biochemical systematics or by stopping the ingestion of available nutrients to the microorganisms. In the present investigations, the antibacterial activity of stem, leaf and root of B. procumbens against phytopathogenic bacteria such as $C$. michiganensis and $X$. campestris are reported for the first time. These bacterial strains also showed a strong inhibitory effect in stem and leaf extracts than root extracts. Baskaran et al. (2011) reported that methanol extract of $B$. diffusa showed a lower zone of inhibition for K. pneumonia $(11 \mathrm{~mm})$ and $S$. aureus $(9 \mathrm{~mm})$ as compared to our results. The methanol soluble fraction of $B$. repens displayed higher activity against $S$. aureus $(12.2 \mathrm{~mm})$, B. subtilis $(11.8 \mathrm{~mm})$ and E. coli $(16.7 \mathrm{~mm})$ than the methanol leaf extract of plant sample (Rahman et al., 2014). However, the petroleum ether and carbon tetrachloride fractions of $B$. repen showed mild activity against $A$. niger as compared to our results recorded for leaf and root extracts of B. procumbens (Dey et al., 2012).

\section{Conclusion}

Stem and root of B. procumbens contain vital nutrients suggesting its use as a supplement for human diet and may be added in fodder for livestock with reasonable safety. The in vitro antimicrobial evaluation of leaf extract shows that there is a huge potential for development of new antibiotic drugs.

\section{References}

Abd EI-Salam NM, Hussain I, Ullah R, Ahmad S, Khan S. Essential oil and heavy metals analysis of Boerhaavia procumbens. Life Sci J. 2013; 10: 955-58.

Abdalla EM. Plants: An alternative source for antimicrobial. J Appl Pharm Sci. 2011; 01: 16-20.

Ahmad S, Rahman AU, Fatima K, Bader Y. Amino acid analysis of intellan, a herbal product used in enhancing brain function. Pakistan J Pharm Sci. 1994; 7: 17-24.

AOAC. Official methods of analysis (Association of official analytical chemists). 15th ed. Washington DC, 2005, 12-13.

AOAC. Official methods of analysis international, 18th ed. Washington, DC, 2000.

Baskaran C, Sivamani P, Rathabai V. Evaluation of phytochemical and antimicrobial activities of Boerhavia diffusa. J Pharm Res. 2011; 4: 434-36.

Bokhari J, Khan MR. Evaluation of anti-asthmatic and antioxidant potential of Boerhavia procumbens in toluene diisocyanate (TDI) treated rats. J Ethnopharmacol. 2015; 172: 377-85.

Bokhari J, Rashid M, Ihsan K. Assessment of phytochemicals, anti-oxidant, and anti-inflammatory potential of Boerhavia procumbens Banks ex Roxb. Toxicol Indus Health. 2015; 32: 1456-66.

Bonjar GHS, Aghighi S, Nik AK. Antibacterial and antifungal survey in plants used in indigenous herbal-medicine of South East regions of Iran. J Biol Sci. 2004; 4: 405-12.

Canli K, Altuner E, Akata I, Turkmen Y, Uzek U. In vitro antimicrobial screening of Lycoperdon lividum and determination of the ethanol extract composition by gas chromatography/mass spectrometry. Bangladesh J Pharmacol. 2016; 11: 389-94.

Cowan MM. Plant products as antimicrobial agents. Clin Microbiol Rev. 1999; 12: 564-82.

Dey A, Rahman SMA, Hossain MDM, Hamiduzzaman MD, Alvi MRUH. Evaluation of the anti-oxidant, cytotoxic and antimicrobial activities of the plant Boerhavia repens (Family: Nyctaginaceae). J Pharm Res. 2012; 5: 4063-65.

Gul F, Shinwari ZK, Afzal I. Screening of indigenous knowledge of herbal remedies for skin diseases among local communities of North West Punjab. Pak J Bot. 2012; 44: 160916.

Gupta A, Yadav N. Nutritional and antinutritional factors of underutilized Boerhavia diffusa leaves grown in Northern India. Asian J Dairy Food Res. 2013; 32: 246-48.

Harborne JB. Phytochemical methods: A guide to modern techniques of plant analysis. London, Chapman and Hill, 1973.

Hussain I, Khan L, Mehmood T, Khan I, Ullah W, Khan H. Effect of heavy metals on the growth and development of Silybummarianum, in various polluted areas of Peshawar, Pakistan. J Chem Soc Pak. 2005; 27: 367-73.

James CS. Analytical chemistry of food. 1st ed. Springer, New York, 1995, p 178.

Juna Beegum GR, Beevy SS, Sugunan VS. Qualitative phytochemical screening and GC-MS analysis of Boerhavia diffusa L. Int J Emerging Technol Adv Engineering. 2014; 4: 318-24.

Leon C. Amino acid in therapy. Thorson Publisher Ltd., New York, 1986.

McEntee WJ, Crook TH. Glutamate: Its role in learning, memory, and the aging brain. Psychopharmacology 1993; 111: 391-401. 
Miralles J, Noba K, Ba AT, Gaydou EM, Kornprobst JM. Chemotaxonomy in nyctagynaceae family: Sterols and fatty acids from the leaves of three Boerhaavia species. Bio Systematics Eco. 1988; 16: 475-78.

Nadeem M, Shinwari ZK, Qaisar M. Screening of folk remedies by genus Artemisia based on ethnomedicinal surveys and traditional knowledge of native communities of Pakistan. Pakistan J Bot. 2013; 45: 111-17.

National committee for clinical laboratory standards (NCCLS). Methods for dilution antimicrobial susceptibility tests for bacteria that grow aerobically; approved standard. National Committee for Clinical Laboratory Standards, Wayne, Pennsylvania, USA, 2002.

Nieman DC, Butterworth DE, Nieman CN. Nutrition W.M.C. Brown Publishers, Dubuque, 1992.

Parekh J, Chanda S. Phytochemical screening of some plants from Western regions of India. Plant Arch. 2008; 8: 657-62.

Pérez-Urria CE, Avalos García A. Metabolismo secundario de plantas. REDUCA 2009; 2: 119-45.

Puranik V, Tripathi DQ, Kaur D, Chauhan DK. Nutritional evaluation of leaves of Boerhaavia diffusa L. and Andrographis paniculata (burm.F.) wall: Implications for nutraceautical applications. Inter J Pharma Bio Sci. 2012; 3: 315-21.

Rahman SM, Alam MM, Amin MR, Fakruddin M, Shahid-udDaula AFM, Siddiqui R. Antimicrobial activity and brine shrimp toxicity of methanolic whole plant extract of Boerhavia repens L. (Family: Nyctaginaceae). Int J Pharm. 2014; 4: 135-39.

Rajani M, Kanaki NS. Phytochemical standardization of herbal drugs and polyherbal formulations. In: Bioactive molecules and medicinal plants. Ramawat KG, Merillon JM (eds). 2008, pp 349-69.

Rajkumar K, Malathi R. Phytochemical investigation GC-MS analysis and in vitro antimicrobial activity of Coleus forskohlii. Bangladesh J Pharmacol. 2015; 10: 924-30.

Sankaranarayanan S, Bama P, Ramachandran J, Kalaichelvan PT, Deccaraman M, Vijayalakshimi M, Dhamotharan R, Dananjeyan B, Bama SS. Ethnobotanical study of medicinal plants used by traditional users in Villupuram district of Tamil Nadu, India. J Med Plants Res. 2010; 4: 1089-110.

Shaheen H, Qureshi R, Akram A, Gulfraz M. Some important medicinal flora of Noorpur Thal, Khushab, Pakistan. Arch Sci. 2012; 65: 1661-64.

Shimada T. Salivary proteins as a defense against dietary tannins. J Chem Ecol. 2006; 32: 1149-63.

Shinwari ZK, Malik S, Karim AM, Faisal R, Qaiser M. Biological activities of commonly used medicinal plants from Ghazi Brotha, Attock district. Pakistan J Bot. 2015; 47: 113-20.

Shinwari ZK, Gilani SA, Khan AL. Biodiversity loss, emerging infectious diseases and impact on human and crops. Pakistan J Bot. 2012; 44: 137-42.

Steel RGD, Torrie JH and Dickey DA. Principles and procedures of statistics: A biometrical approach. 3rd ed. New York, McGraw Hill Book Co. Inc., 1997, pp 172-77.

Trease GE, Evans WC. Pharmacognosy. 15th ed. Berlin, Springer, 2002.

Ujowundu CO, Igwe, CU, Enemor VHAL, Nwaogu A, Oka for OE. Nutritive and anti-nutritive properties of Boerhavia diffusa and Commelina nudiflora leaves. Pakistan J Nutr. 2008; 7: $90-92$.

Wallace L, Boxal M, Riddick M. Influencing exercise and diet to prevent osteoporosis: Lessons from 3 studies. $\mathrm{Br} \mathrm{J}$ Community Nurs. 2004; 3: 102-09.

World Health Organization. Quality control methods for medicinal plant materials. Geneva, WHO, 1998. 